\title{
IS THERE A ROLE FOR EXTRACELLULAR MATRIX IN THYMUS PHYSIOLOGY AND PATHOLOGY?
}

\author{
WILSON SAVINO ${ }^{+}$\& JOSELI LANNES VIEIRA \\ Instituto Oswaldo Cruz, Departamento de Imunologia, \\ Caixa Postal 926, 20001 Rio de Janeiro, RJ, Brasil
}

Extracellular matrix (ECM) components are known to play important roles in a large series of biological phenomena, including cell spreading, migration and differentiation (reviewed by Watt, 1985; Dufour et al., 1988), as well as parasite invasiveness and host defense (Ouassi, 1988; Saba \& Jaffe, 1980). A correlation has been observed between the presence of fibronectin (FN) and the migrations of distinct cell types during ontogeny (Critchley et al., 1979; Dierterlen-Lievre \& Martin, 1981; Thiery et al., 1982). In respect of the thymus, such a correlation has also been shown, being refleted by the entrance of lymphoid precursors into the thymic anlagen (Savagner et al., 1988), which is in keeping with the presence of FN binding sites, detected in thymocytes, and more particularly in the immature subsets (Trowbrige et al., 1982; Fowlkes et al., 1985; Cardarelli \& Pierbachbacher, 1986; Cardarelli et al., 1988). Taken together, these initial data suggested a role for extracellular matrix in thymocyte differentiation.

In the present review, we shall summarize a series of results recently obtained in our and other laboratories, that support and extend the concept that extracellular matrix proteins may play a multifaceted role in the physiology and pathology of the thymus. Nonetheless, before going into functional data, it appears worthwhile to provide some background on the distribution of ECM proteins within the normal thymus.

\section{INTRA-THYMIC DISTRIBUTION OF EXTRACELLULAR MATRIX PROTEINS}

Extracellular matrix components on the thymus were initially investigated by histological means, with the distribution of reticulin and elastic system fibers being described (Henry, 1967; Savino, 1982). Recently, the location of ECM molecules was more

This work was partially supported with grants from $\mathrm{CNPq}$ (Brazil), INSERM (France), DAAD (Germany) and CEC (Brussels).

\footnotetext{
+ Corresponding author.
}

finely analyzed in the normal human thymus by im. munohistochemical methods (Berrih et al., 1985). This study revealed the existence of basement membrane proteins in intralobular sites including the medulla, in contrasting to the septal restricted distribution of type I collagen (TI-C). Similarly, we showed that in young mice, type I collagen was restricted to the interstitial spaces of the capsule and septa, where type IV collagen, fibronectin and laminin could be detected in the basement membranes. Additionally, these proteins were seen within the medulla of the thymic lobules forming a fine network (Lannes Vieira et al., 1991a) as depicted in Fig. 1a. Interestingly, aging as well as autoimmune conditions yielded an intralobular ECM network denser than that of young adult normal animals.

Ontogenetic studies evidenced a distinct ECM distribution pattern in the developing embryos, since by day 15 , the fetal thymus presented a fine meshwork of basement membrane containing proteins throughout the parenchyme. As detailed below, this may be related to thymocyte differentiation.

Lastly, in vitro studies revealed that thymic epithelial cells (TEC) can produce type IV collagen, laminin and fibronectin (Berrih et al., 1985; Savino et al., 1986; Lannes Vieira et al., 1991a), suggesting that they are responsible (at least in part) for the intrathymic basement membrane protein production (Fig. 2).

\section{ABNORMAL INTRA-THYMIC ECM-CONTAINING NETWORK IN IMMUNODEFICIENCIES}

Besides the normal distribution pattern of basement membrane proteins, abnormal ECMcontaining networks can be found in some immunodeficiency conditions, in which high numbers of intra-thymic B lymphocytes and/or immunoglobulins bound to ECM structures are associated. 


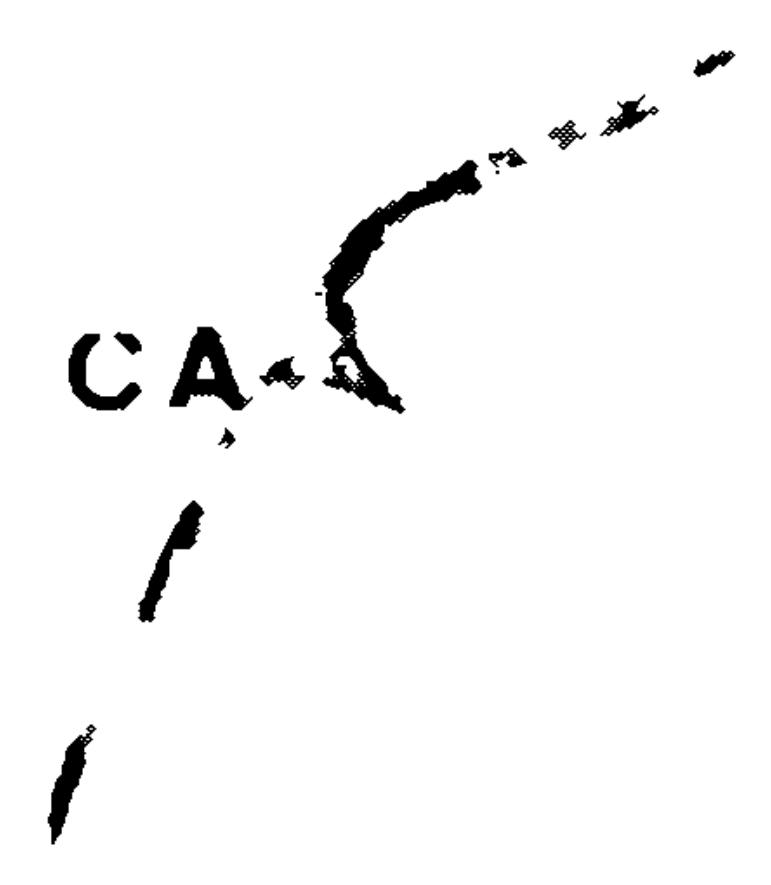

C

$\mathbf{M}$
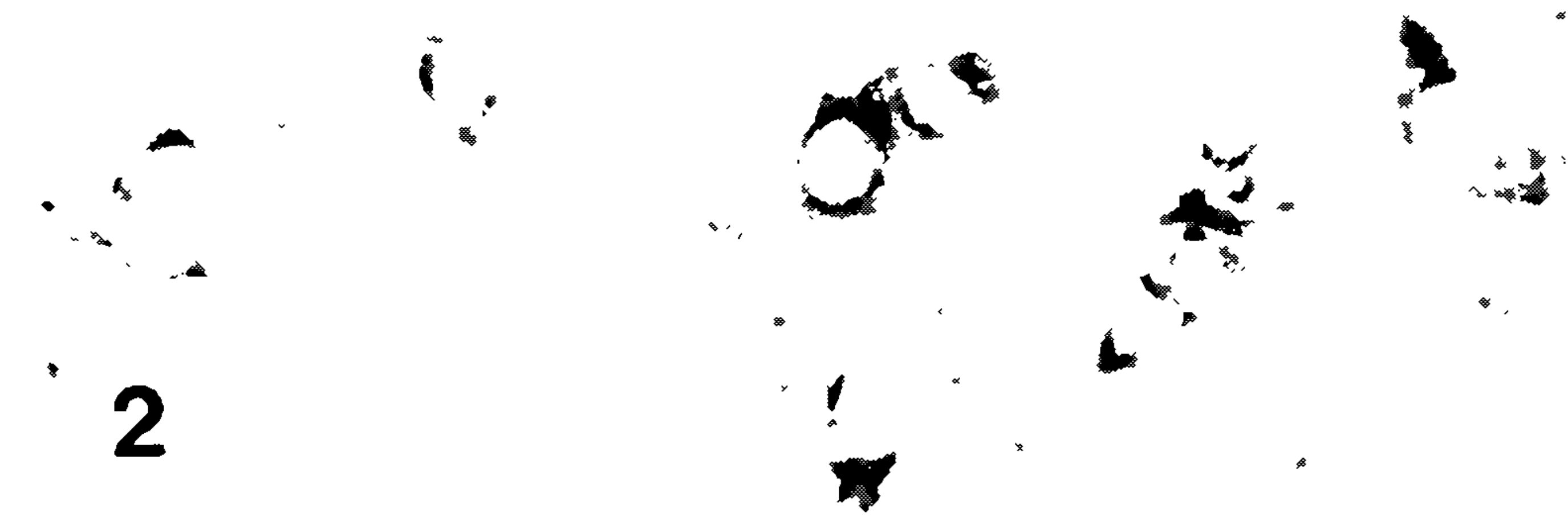

Fig. 1: immunoperoxidase detection of fibronectin on a normal young adult mouse thymus frozen section. Note that capsulary basement membrane is strongly labeled, together with a posivite reaction forming a network in the medulla. CA: capsule; $\mathrm{C}$ : cortex; M: medulla. X450. Fig. 2: in vitro production of laminin by the thymic epithelial cell-line (IT-76M1) as assessed by immunohistochemical labeling. X450.

Some years ago, we evidenced an intralobular, cortical ECM-containing network in hyperplastic thymuses of myasthenia gravis (MG) patients (Savino \& Berrih, 1984). These novel structures occurred adjacently to the intraseptal $B$ cell containing lym- phoid follicles, and the basement membrane at these sites exhibited several ruptures. Additionally, we showed that collagen breakdown in these areas was enhanced (Savino et al., 1988a). Interestingly, the adjacently subseptal TEC layer exhibit- 
ed monoclonal antibody-defined phenotypic changes (Savino et al., 1988b). Lastly, perivascular spaces in MG-associated thymuses were shown to be increased and to contain an ECM-containing meshwork (Muller-Hammerlink \& Wekerle, 1986).

A cortical ECM network was also observed in thymuses from Down's syndrome (DS) patients. Differently from myasthenia gravis, no lymphoid follicles were found close these structures in DS thymuses (Fonseca et al., 1989). Nonetheless, it is interesting to note the presence of immunoglobulins bound to basement membranes. Moreover, sera from some DS patients present circulating antibodies able to bind to thymic ECM structures (our unpublished data).

More recently, circulating anti-ECM antibodies were detected in the non-obese diabetic (NOD) mouse (Savino et al., 1991), which spontaneously develop an autoimmune type I diabetes, and exhibits intra-thymic lymphoid follicles. Additionally, we found immunoglobulins bound to intralobular ECM strutures. Yet, one of the most striking abnormality in the NOD mouse thymic microenvironment was the existence of giant perivascular spaces in which both $\mathrm{T}$ and $\mathrm{B}$ lymphocytes could be evidenced, intermingled with an ECM-containing network. It is noteworthy that abnormal perivascular spaces were also detected in another animal model of type I diabetes, namely the BB rat ( Schuurman et al., 1990).

Similarly to the data reported for MG, ruptures in the basement membrane as well as in the subseptal epithelial layer were also detected in the NOD mouse thymus (Savino et al., 1991).

Taken together, these findings suggest that abnormal ECM-containing networks may be associated with pathological $B$ and/or $T$ lymphocyte migration within the thymus. In respect to the NOD mouse model, preliminary findings suggest the existance of an abnormal traffic of lymphocytes from the thymus.

\section{INCREASE OF THYMIC ECM IN ACUTE INFECTIOUS DISEASES: RELATIONSHIP TO THYMOCYTE DEATH}

A further aspect to be discussed concerns the modulation of the extracellular matrix component of the thymic microenvironment, and its parallelism with thymocyte death. In the last few years we cumulated evidence showing that the expression of basement membrane proteins, namely type IV collagen, laminin and fibronectin, is dramatically increased in atrophic thymuses. Thus, in a variety of experimental and human infections resulting in severe thymocyte depletion, an important intralolular ECM-containing network was consistently observed, as in murine rabies (Savino et al., 1987), acute experimental Chagas' disease (Savino et al., 1989), schistosomiasis (Silva Barbosa et al., 1990) as well as congenital human measles or cytomegalovirus infections (Fonseca et al., 1990). Interestingly, this phenomenon was also evidenced after infecting mice with a single dose of hydrocortisone, known to promote thymocyte death (Lannes Vieira et al., 1991a). Kinetic studies in both hydrocortisone, T. cruzi and S. mansoni in vivo models revealed that such increase in ECM production actually preceeds thymocyte depletion. These data together with our preliminary findings suggesting that fibronectin appears to enhance thymocyte death in vitro, raised the hypothesis that the increase in thymic extracellular matrix occurring as a general feature in acute infectious diseases, may be somewhat related to thymocyte death.

\section{MODULATION OF THYMOCYTE DIFFERENTIATION WITH ANTI-ECM ANTIBODIES}

Very recently, we asked the question whether the modulation of thymic ECM by anti-ECM antibodies could somewhat influence thymocyte differentiation. For that, two models are presently being investigated in our laboratory: an in vitro system corresponding to the thymic nurse cell complex, and the in vivo strategy with injection of antiECM antibodies into pregnant mice with subsequent analysis of the offspring thymuses.

Studies on the thymic nurse cell complex - The thymic nurse cell (TNC) complex was initially reported by Wekerle \& Ketelson (1980), that obtained in vitro a large multicellular structure comprised of one thymic epithelial cell surrounding 20-200 thymocytes. These latter appear to partially diferentiate within TNC, and when the complex is cultured, they are released from TNC in 24-72 h. 
We observed that, when TNC complex was cultured in the presence of anti-fibronectin or antitype IV collagen (and to a lesser extent anti-laminin) antibodies, thymocyte release into the culture medium was dramatically decreased (Villa Verde \& Savino, this Vol.). This strongly suggests that the modulation of ECM production by TNC may influence the differentiation of respective thymocytes.

In vivo injection of anti-ECM antibodies - When pregnant mice were treated with a single dose of anti-FN or anti-type IV collagen antibody, thymic relative weight as well as the total number of viable thymocytes were consistently increased as compared to controls (Fig. 3). Nonetheless, the percentage numbers of the four CD4/CD8-defined thymocyte subsets did not exhibit any significant changes. Most importantly, there was a down regulation of the $\mathrm{CD} 3$ complex following antifibronectin - but not anti-laminin - antibody treatment as shown in Fig. 4.

\section{IN VIVO EFFECTS OF ANTI-ECM ANTIBODIES ON THYMUS WEIGHT}

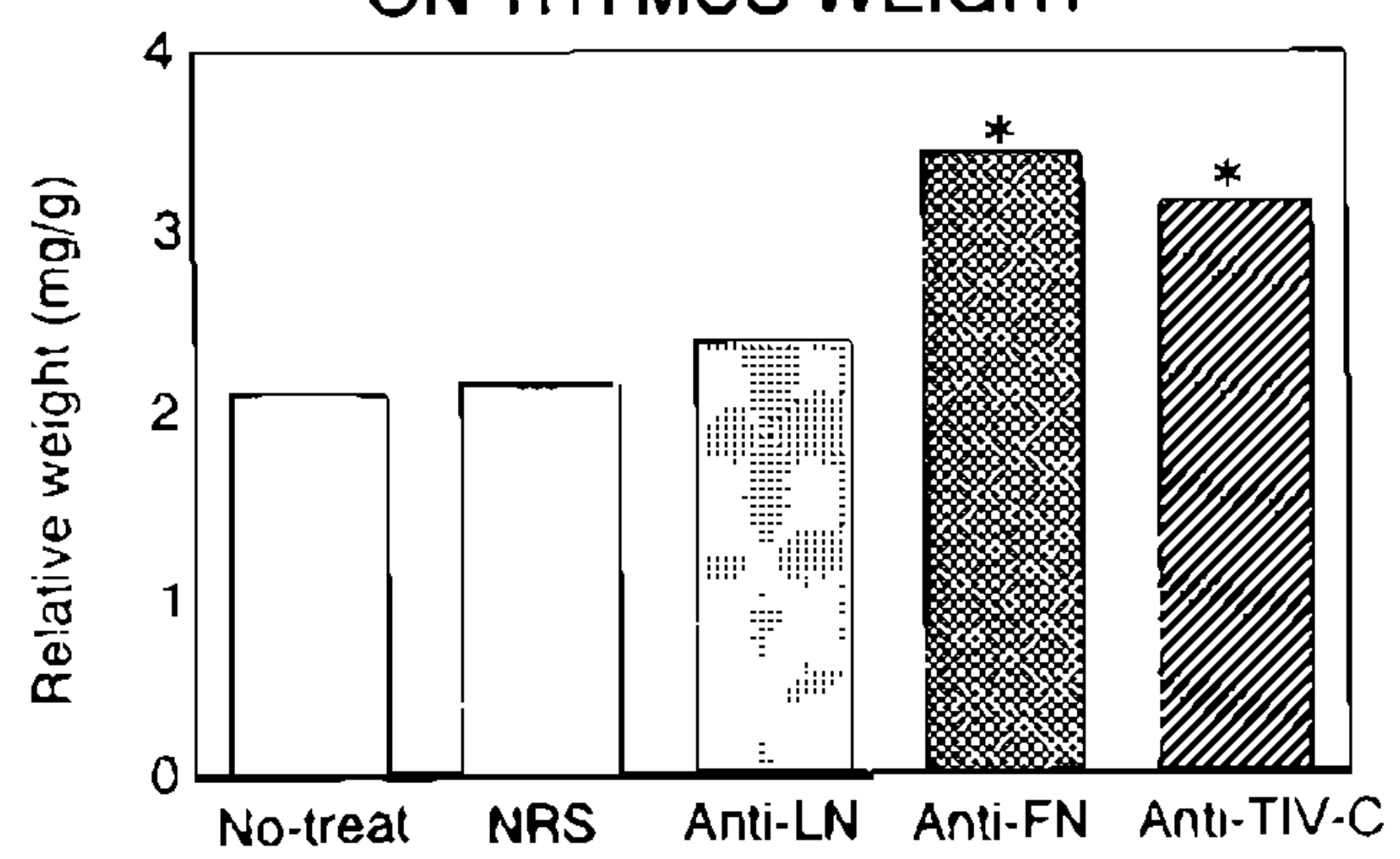

Fig. 3: increase in relative thymic weight in thymuses from day 19 fetuses, whose mothers were injected with distinct anti-ECM antibodies or respective controls. Note the significant increase in thymus weight upon injection of antiFN or anti TIV-C, but not anti-LM.

These findings suggest that a modulation of fibronectin by in vivo injection of corresponding antibody yields important changes in the physiological program of thymocyte differentiation. Such modulation is probably due to a direct intra-thymic effect of the anti-FN antibody, since traces of the antibody could be detected by immunoelectronmicroscopy within the thymic parenchyme. This anti-FN effect likely triggers a feedback circuit inducing microenvironmental cells to modulate fibronectin production, that would ultimately influence differentiating thymocytes, which, as previously mentioned, bear FN-receptors.

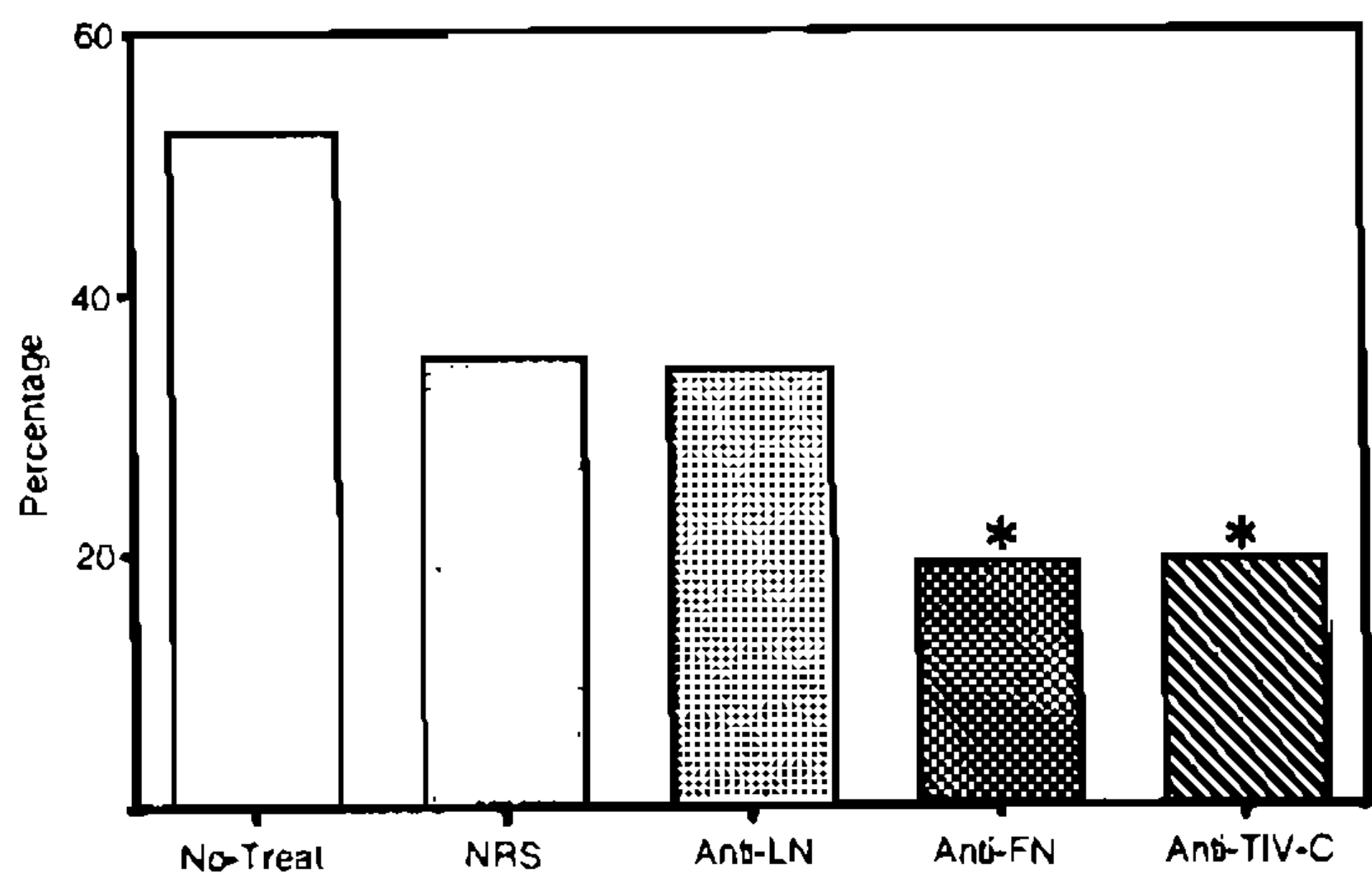

Fig. 4: decrease in the percentage numbers of $C D 3$-bearing thymocytes of 19 day fetal thymuses, after a single injection of distinct anti-ECM antibodies into respective pregnant mice. Note that the effect could be obtained with both anti-FN and anti-TIV-C antibodies, whereas the anti$\mathrm{LM}$ did not yield significant changes in $\mathrm{CD}^{3}{ }^{+}$cell numbers. Data for the CD3 complex were obtained by flow cytometry.

\section{INTERFERON-GAMMA-INDUCED MODULATION OF THYMIC EXTRACELLULAR MATRIX: RELATIONSHIP WITH TEC PROLIFERATION}

Taking into account that ECM components appear to modulate thymocyte differentiation during thymus ontogeny, one could imagine that the production of ECM molecules might also be under influence of the differentiating thymocytes themselves. The rationale for that is based on the concept that bi-directional interactions between mesenchymal-derived cells with epithelial (endodermal- or ectodermal-derived) cells actually correspond to a common phenomenon in organogenesis (reviewed in Deucher, 1975).

It was previously showed that interferon-gamma (IFN-g) can re-induce the expression of HLA-DR in primary cultures of human TEC, normally lost when these cells are settled to grow in vitro (Berrih et al., 1986). Additionally, Ia expression by thymic nurse cells, as well as their adhesion to differentiating thymocytes, are enhanced by IFN$\mathrm{g}$ (Defresne et al., 1990).

We studied the effects of recombinant interferon-g (rIFN-g) on some aspects of two murine TEC lines. Besides the expected induction of MHC class II antigens, this lymphokine was able to modulate ECM production by growing TEC, as well as their adhesion and proliferation patterns (Lannes Vieira et al., 1991b).

As regards the influence of IIFN-g on ECM expression, we observed that when applied in very low 


\section{IN VITRO DOSE-DEPENDENT EFFECTS OF IFN- $\triangle$ UPON THYMIC EPITHELIAL CELLS}

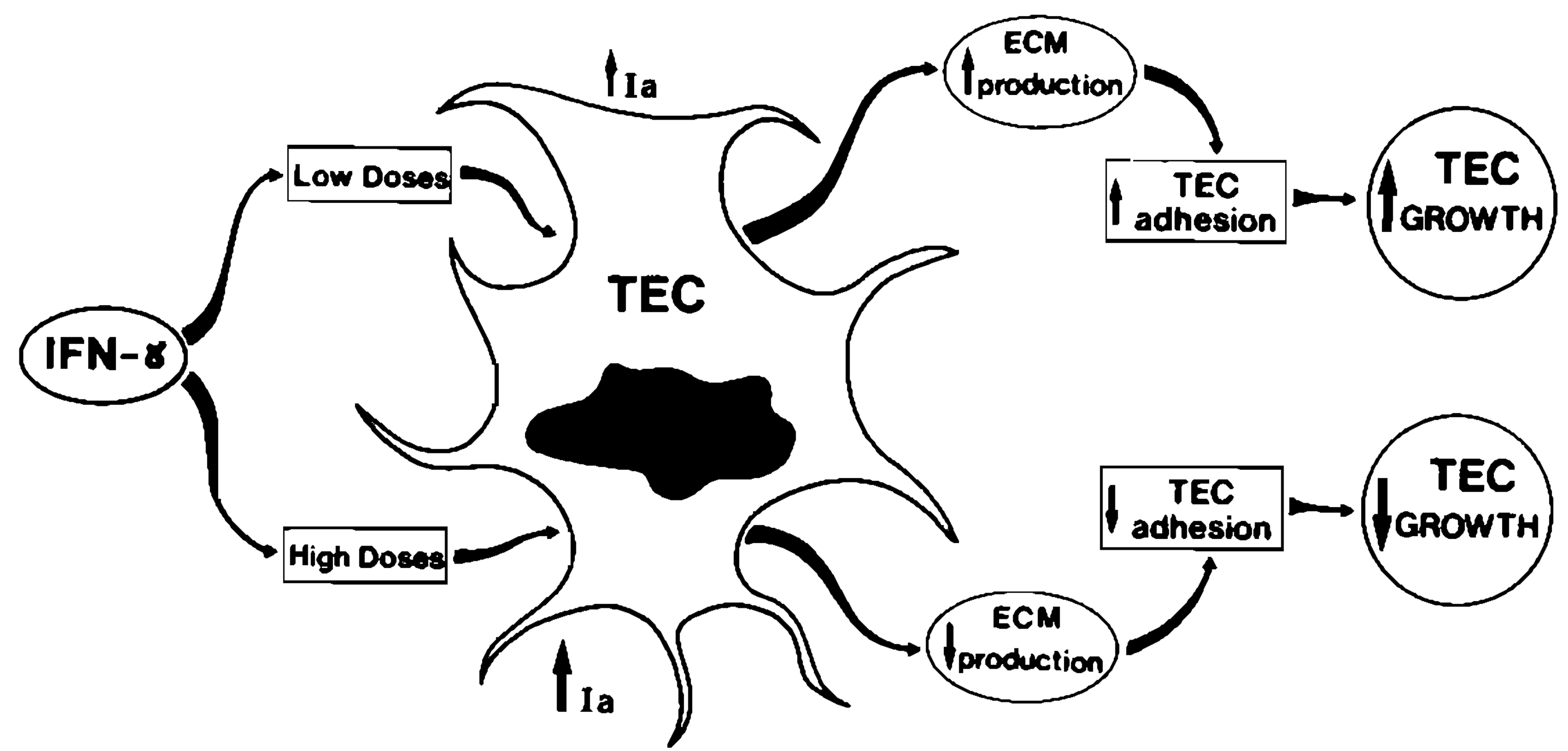

Fig. 5: diagram illustrating the effects of IFN-g upon the proliferation of cultured thymic epithelial cells. Low or high doses of the lymphokine respectively induce an enhancement or decrease in the production of basement membrane proteins. This event will be, at least partially, responsible for the consequent enhancement or decrease in TEC proliferation.

doses, it promoted an increase in the amounts of basement membrane proteins, mainly fibronectin. In contrast, relatively high doses of this lymphokine $\left(10^{1}\right.$ to $\left.10^{2} \mathrm{IU} / \mathrm{ml}\right)$ induced the opposite effect. Interestingly, both the stimulatory and blocking effects of rIFN-g on ECM expression were paralleled by equivalent modulation on cell proliferation. These effects could be significantly abrogated by an anti-IFN-g monoclonal antibody.

Searching whether the rIFN-g effects on ECM were related to TEC proliferation, we attempted to correlate the pattern of TEC growth with the amounts of ECM production upon different doses of rIFN-g. For that, "virgin" TEC (that received no rIFN-g treatment) were plated onto ECM substrata produced by other TEC upon rIFN-g influence. Actually, we evidenced that increase or decrease in TEC adhesion and proliferation positively correlated with the dose-dependent IFNinduced increase or decrease in ECM production. These data are summarized in Fig. 5.

This series of experiments suggests that one thymocyte derived cytokine, namely IFN-g participates in the control of extracellular matrix production by thymic epithelial cells. Yet, further studies are necessary to demonstrate if such effects are relevant during thymus ontogeny.

\section{CONCLUSIONS AND PERPECTIVES}

In this review we summarized data from different kinds of experiments converging to the general concept that the physiology of the thymus, in terms of both lymphoid and microenvironmental compartments are under influence of extracellular matrix components. Secondly, the regulation of ECM production by the thymic epithelium may be under cytokine control, as revealed by the studies with interferon-gamma. Lastly, changes in thymic ECM may be related to pathological aspects in infectious diseases and immunodeficiencies including thymocyte death and $B$ and $T$ cell infiltration.

Although these general hypothetical concepts are attractive, many experiments involving distinct approaches should be carried out. Once accomplished they will help us to establish a complete model explaining the functions of each ECM molecule upon different aspects of thymus physiology and how their production is controlled. Finally, this comprehension shall hopefully throw some light on the putative mechanisms involving abnormal ECM production in thymus pathology. 


\section{REFERENCES}

BACH, J. F., 1983. Thymic hormones. Clin. Im. munol. Allergy. Vol 3. W. S. Saunders, London.

BERRIH, S.; SAVINO, W. \& COHEN, S., 1985. Extracellular matrix of the human thymus: im- unofluorescence studies on frozen sections and cultured epithelial cells. J. Histochem. Cytochem., 99: 655-662.

BERRIH, S.; ARENZANA-SEISEDOS, F.; COHEN, S.; DEVOS, R.; CHARRON, D. \& VIRELIZIER, J. L., 1986. J. Immunol., 195: $1165-1172$.

CARDARELLI, P. M.; CRISPE, I. N. \& PIERSCHBACHER, M. D., 1988. Preferential expression of fibronectin receptors on immature thymocytes. $J$. Cell Biol., 106: 2183-2189.

CARDARELli, P. M. \& PIERSCHBACHER, M. D., 1986. T lymphocyte differentiation and the extracellular matrix: identification of a thymocyte subset that attaches specifically to fibronectin. Proc. Natl Acad. Sci. USA, 88: 2647-2651.

CRITCHLEY, D. R.; ENGLAND, M. A.; WAKELY, J. \& HYNES, R. O. 1979. Distribution of fibronecin in ectoderm of gastrulation chick embryos. $\mathrm{Na}$ ture, 280: 498-499.

DEFRESNE, M. P.; HUMBLET, C.; RONGY, A. M.; GREIMERS, R. \& BONIVER, J., 1990. Eur. J. Im . munol., 20: 429.

DEUCHER, E., 1975. Cellular Interactions in De. velopment. Academic Press, London.

DIETERLEN-LIEVRE F. \& MARTIN, C., 1981. Diffuse intraembryonic hemopoiesis in normal and chimeric avian development. Develop. Biol., 88: 180-187.

DOUROV, N., 1986. Thymic atrophy and immune deficiency in malnutrition, p. 127-150. In H. K. MullerHermelink, The human thymus. Histophysiolo. gy and Pathology. Spriger-Verlag, Berlin.

DUFOURS, S.; DUBAND, J. L.; KORNBLIHTT, A. R. \& THIERY, J. P., 1988. The role of fibronectins in embryonic cell migrations. Trends Genet., 4: 198-201.

FONSECA, E. C.; VILLA VERDE, D.; LANNES VIEIRA, J.\& SAVINO, W., 1989. Thymic extracellular matrix in Down's syndrome. Braz. J. Med. Biol. Res., 28: $971-974$.

FOWLKES, B. J.; EDSON, L.; MATHIESON, B. J.\& CHUSED, T. M., 1985. Early T lymphocytes. Differentiation in vivo of adult intrathymic precursor cells. J. Exp. Med., 162: 802-809.

JENKINSON, E. J.; VAN EWIJK, W.\& OWEN, J. J. T., 1981. Major histocompatibility complex antigen expression on the epithelium of developing thymus in normal and nude mice. J. Exp. Med., 15\$: 280, 1981.

LANNES VIEIRA, J.; DARDENNE, M. \& SAVINO, W., 1991a. Extracellular matrix components of the mouse thymus microenvironment. I. Ontogenetic studies and modulation by glucocorticoid hormones. J. Histochem. Cytochem., 39: 1539-1546.

LANNES VIEIRA, J.; VANDER MEIDE, P. H. \&
SAVINO, W., 1991b. Extracellular matrix components of the mouse thymic microenvironment. II. In vitro modulation of basement membrane proteins by interferon- $\gamma$ : relationship with thymic epithelial cell proliferation. Cell Immunol., 197: 329-340.

MUI I.t.R-HEMMERI.INK, H. K. \& WH:KERI.E, H., 1986. The thymus in myasthenia gravis. In. H. K. Muller-Hermilink, The human thymus. Hislophysiology and Pathology. Spriger-Verlag. Berlin.

NONOYAMA, S.; NAKAYAMA, M.; SHIOHARA, T. \& YATA, J., 1989. Only dull CD3 thymocytes bind to thymic epithelial cells. The binding is elicited by both CD2/LFA-3 and LFA- 1/ICAM-1 interactions. Eur. J. Immunol., 19: 1631-1635.

OUAISSI, M. A., 1988. Role of the RGD sequence in parasite adhesion to host cells. Parasitol. Today, 4: $169-171$.

SABA. T. M. \& JAFFE, E., 1980. Plasma fibronectin (opsonic glycoprotein): its synthesis by vascular endothelial cells and role in cardiopulmonary integrity after trauma as related to reticulo-endothelial function. Am. J. Med., 68: 577-585.

SAVAGNER, P.; BAUVOIS, B.; DEUGNIER, M. A.; IMHOF, B. A. \& THIERY, J.-P., 1989. Aspects of haematopoietic cell dynamics: ontogeny and target migration. Ann. Inst. Pasteur/Immunol., 199: 409.425.

SAVINO, W., 1982. The elastic system in the thymus of the opossum Didelphis marsupialis aurita. Anat. Anz., 151: 70-74.

SAVINO, W. \& BERRIH, S., 1984. Thymic extracellular matrix in myasthenia gravis. Lancet, ii: 65-66.

SAVINO, W.; IMHOF, B.; ITOH, T. \& DARDENNE, M., 1986. Immunohistochemical phenotypic studies on thymic stromal cell lines. Thymus

SAVINO, W.; DAUGUET, C. \& TSIANG, H., 1987. Severe changes in the thymus of rabies virus infected mice. Abstract. Joint Meeting of Eur. Soc. against Virus Diseases and Eur. Group for rapid Viral Diagnosis. Davos.

SAVINO, W.; EMONARD, H. \& GRIMAUD, J.-A., 1988a. Thymic extracellular matrix in Myasthenia gravis. 11. Immunohistochemical evidence $f_{Q r}$ increased type I collagen degradation. J. Neuroimmunol., 18: 223-227.

SAVINO, W.; TAKACS, L.; MONOSTOR1, E. \& DARDENNE, M., 1988b. Phenotypic changes of the subseptal thymic epithelium in myasthenia gravis. Thymus, 12: 111-116.

SAVINO, W.; LEITE DE MORAES, M. C.; HONTEBEYRIE-JOSKOWICZ, M. \& DARDENNE M., 1989. Studies on the thymus in Chagas' disease. I. Changes in the thymic microenvironment in mice acutely infected with Trypanosoma cruzi. Eur. J. Immunol., 19: 1727-1733.

SAVINO, W.; BOITARD. C.; BACH, J. F. \& DARDENNE, M., 1991. Studies on the thymus in nonobese diabetic (NOD) mice. I. Changes in the microenvironmental compartments. Lab. Invest., 64: 647-661. 
SILVA BARBOSA, S. D.; LANNES VIEIRA, J.; VI LAR, M. M., TENDLER, M. \& SAVINO, W., 1990. Studies on the thymus in murine schistosomiasis. 2nd Congress on the Latin American Society of Immunology. Abstract book, p. 47.

STEMBERG, J. \& KIMBER, S. J., 1980. Distribution of fibronectin, laminin and entactin in the environment of migranting neural crest cells in early mouse embryos. J. Embryol. Exp. Morphol., 91: 267-276.

THIERY, J. P.; DUBAND, J. L. \& DELOUVEE, A.,
1982. Pathways and mechanisms of avian trunk neural crest cell migration and localization. Develop. Biol., 98: 324-331.

TROWBRIGE, 1. S.; LESLEY, J.; SCHULTE, R.; HYMAN, R.\& TROTTER, J., 1982. Biochemical characterization and cellular distribution of polymorphic murine cellular surface glycoprotein expressed on lymphoid tissues. Immunogenetics, 15: 999-1003.

WATT, F. M., 1986. The extracellular matrix and cell shape. Trends Biochem. Sci., 11: 482-485. 